Japan. J. Med. Sci. Biol., 34, 9-20, 1981

\title{
CHARACTERISTICS OF MURAYAMA VIRUS IN VARIOUS CELL CULTURES AND LABORATORY ANIMALS
}

\author{
Fumio NISHIKAWA, Kirgi YAMAMOTO and Teiji SUgIYAMA \\ Department of Virology and Rickettsiology, National Institute of Health, \\ Kamiosaki, Shinagawa-ku, Tokyo 141
}

(Received, July 2, 1980. Accepted, December 12, 1980)

\begin{abstract}
SUMMARY: Some biological properties of Murayama virus, a new paramyxovirus, were studied. The virus grew well in primary monkey kidney cells as well as embryonated eggs, while the virus yields in primary chick embryo and BHK-21 cells were much lower. The infected BHK-21 cells formed large syncytia and showed typical hemadsorption, but did not produce any detectable amount of hemagglutinin in the culture fluid. The virus yields were very low in Vero, LLC-MK2 and MDCK cells at first passages. The addition of trypsin to the medium enhanced virus growth in Vero and LLC-MK2 but not in MDCK cells. Cell fusion activity of the virus was observed in Molt-4 cells. Hemolytic activity was enhanced by freezethawing.

Several species of mammals and birds were susceptible to experimental infections with the virus as evidenced by seroconversion and positive virus isolation without showing any clinical signs.
\end{abstract}

\section{INTRODUGTION}

In the preceding paper, we reported that a new virus designated as Murayama virus was isolated from cynomolgus monkeys (Macaca fascicularis) with mild upper respiratory signs. The virus grew well in chick embryos and primary monkey kidney (MK) cells, formed syncitia and cytoplasmic inclusion bodies in infected MK cells, agglutinated some avian and mammalian red blood cells, and possessed neuraminidase and hemolytic activities. From these biological properties and morphological features, Murayama virus was identified as a paramyxovirus. However, there was no antigenic relationship between Murayama virus and any other paramyxovirus available in this laboratory except Yucaipa and Bangore viruses, with which only one-way antigenic relationships were observed (Nishikawa, Sugiyama and Suzuki, 1977a). Recently, many paramyxoviruses have been isolated from animals, especially from domestic and wild birds, and their serological relationships have been studied (McFerran et al., 1974; Collings et al., 1975; Smit and Rondhuis, 1976; Webster et al., 1976; Yamane et al., 1978; Shortridge and Alexander, 1978; Alexander et al., 1979).

In this communication, we describe further studies on the biological proper-

西川文雄・山本紀一・杉山貞次（国立予防衛生研究所 ウイルス・リケッチャ部） 
ties of Murayama virus, mainly on the growth characteristics in some tissue culture cells and the susceptibilities of some laboratory animals to the virus.

\section{MAterials AND Methods}

Virus: 12344NT strain isolated from a monkey (Nishikawa et al., 1977a) was used throughout the present experiments as the prototype of Murayama virus. Infectivity titers of the virus grown in chick embryos and MK cells were about $10^{8} \mathrm{EID}_{50}$ and $10^{7} \mathrm{TCID}_{50}$ per $\mathrm{ml}$, respectively.

Cell cultures: As primary cell cultures, MK and chick embryo (CE) cells were used. Continuous lines of BHK-21, Vero, LLC-MK2 and MDCK cells were also used. MK cells were grown in Earle's balanced salt solution with $0.5 \%$ lactalbumin hydrolysate (LE) plus $2 \%$ calf serum, and maintained in LE plus $0.1 \%$ yeast extract. CE, BHK-21, Vero and LLC-MK2 cells were grown in Eagle's minimum essential medium (MEM) plus 5 to $10 \%$ calf serum and maintained in Eagle's MEM. MDCK cells were cultivated according to Tobita's method (Tobita, 1975) except that bovine serum albumin was omitted from the maintenance medium when trypsin was included. Ehrlich ascites tumor (EAT) cells were harvested from mice and suspended in balanced salt solution containing $1 \mathrm{mM}$ $\mathrm{CaCl}_{2}$ as described by Okada and Murayama (1966). Molt-4 cells were grown in the medium RPMI \# 1640 with 10\% fetal calf serum (Minowada et al., 1972).

Serial passages of virus: Undiluted passages of virus were made in CE, BHK-21, Vero, LLC-MK2 and MDCK cells, and diluted passages at about 1,000fold in MK cells. In 5 or 6 days after inoculation, the cells and culture fluids were once frozen and thawed, and the supernatants of the mixtures after low speed centrifugation (at $1,500 \times \mathrm{g}$ for $10 \mathrm{~min}$ ) were used for the subsequent passages.

Infectivity titration: Serially diluted virus suspensions were inoculated into the allantoic cavity of 10 day-old chick embryos or onto monolayer of MK cells grown in microplates. Hemagglutination (HA) of allantoic fluids after 3 days' incubation or hemadsorption (HAD) on MK cells after 6 to 7 days' incubation were examined, and $\mathrm{EID}_{50}$ or $\mathrm{TCID}_{50}$ were calculated.

Virus growth in $M K$ cells: Monolayers of MK cells in 35-mm petri dishes were washed twice with phosphate buffered saline (PBS) and $0.1 \mathrm{ml}$ of the virus suspension was inoculated onto each dish. The dishes were placed at room temperature for $90 \mathrm{~min}$ with occasional tilting, then at $37 \mathrm{C}$ for $30 \mathrm{~min}$. The monolayers were washed with PBS, treated with $0.2 \mathrm{ml}$ of anti-Murayama virus rabbit serum at $37 \mathrm{C}$ for one hour, washed with PBS and incubated with $2 \mathrm{ml}$ of maintenance medium at $35 \mathrm{C}$. At the intervals indicated, the culture fluid in each of duplicate dishes was removed; the cells were washed with PBS and covered with the original volume of maintenance medium. The fluids and cells were stored at $-75 \mathrm{C}$. Just before virus titration, the frozen cells with the medium were thawed and centrifuged at low speed and the supernatants were used for the materials of cell-associated virus. 
Effect of trypsin on virus growth: An appropriately diluted virus suspension $(0.1 \mathrm{ml})$ was inoculated onto the cell monolayer in $35-\mathrm{mm}$ petri dishes. After the adsorption, the cells were maintained in the medium with or without trypsin (Difco 1:250). After incubation for 5 to 6 days at $35 \mathrm{C}$, virus yield was determined by infectivity and HA titration.

Cell fusion experiment: Cell fusion activity was examined with EAT and Molt-4 cells. With EAT cells, a concentrated suspension of egg-grown Murayama virus was mixed and the cell fusoin was observed microscopically after incubation at $37 \mathrm{C}$ for $30 \mathrm{~min}$ with occasional shaking. With Molt- 4 cells, serial fourfold dilutions of a concentrated suspension of egg-grown Murayama virus were mixed and the mixtures were centrifuged at $200 \times \mathrm{g}$ for $3 \mathrm{~min}$. The pellet was resuspended in a small volume of balanced salf solution containing calcium. The suspension was incubated at $37 \mathrm{C}$ for $1 \mathrm{hr}$ and observed microscopically for cell fusion.

Freeze-thawing experiment: Aliquots of a concentrated suspension of the virus grown in chick embryos or in MK cells were frozen and thawed once to seven times. The treated suspension was titrated for infectivity on MK cells and for hemolytic activity as described (Nishikawa et al., 1977a).

Experimental infection of laboratory animals: All animals were inoculated with small volumes of a suspension of Murayama virus grown in chick embryos containing $10^{8.5} \mathrm{EID}_{50}$ per ml. Monkeys were each inoculated with 0.5 to $1.0 \mathrm{ml}$ of the virus by inhalation or dropping into nostrils under light anesthesia. Mice, hamsters and guinea pigs were each inoculated intranasally under light anesthesia with 0.05 to $0.3 \mathrm{ml}$ of the virus. Bengaleses (Lonchura striata var. domestica Flower), Strawberry finches (Estrilda amandava), quails and 5 to 6 day-old chicks were also inoculated intranasally without anesthesia each with 0.01 to $0.1 \mathrm{ml}$ of the virus.

Virus isolation: From monkeys, throat and nasal swabs were collected every day for 7 days, and in 10 and 14 days after inoculation. Mice and hamsters were sacrificed 5 days after inoculation and the lungs were collected. Bengaleses, strawberry finches and chicks were sacrificed 3, 7, 10 and 14 days, and a quail 5 days after inoculation, and the lung-trachea and cloaca were separately collected. Virus isolation was carried out by inoculation of chick embryos and/or MK cells.

Serological test: Pre-inoculation sera were collected from monkeys, hamsters, guinea pigs and quails, whereas the sera of uninoculated animals were used as pre-inoculation sera in other animals. Antibodies were determined by tha micro method of the hemagglutination-inhibition (HI) test with both pre- and post-inoculation sera. 


\section{Results}

\section{Growth in Cell Cultures}

We have already reported that Murayama virus grew well in chick embryos (Nishikawa et al., 1977a), the virus yield reaching about $10^{8} \mathrm{EID}_{50}$ per $\mathrm{ml}$ of the allantoic fluid. In this study, several cell cultures were tested for their susceptibilities to the virus. The virus grew well in MK cells as mentioned before (Nishikawa et al., 1977a); as shown in Fig. 1, when the virus was inoculated at an input multiplicity of about $100 \mathrm{TCID}_{50}$ per cell, the titers of the virus in the

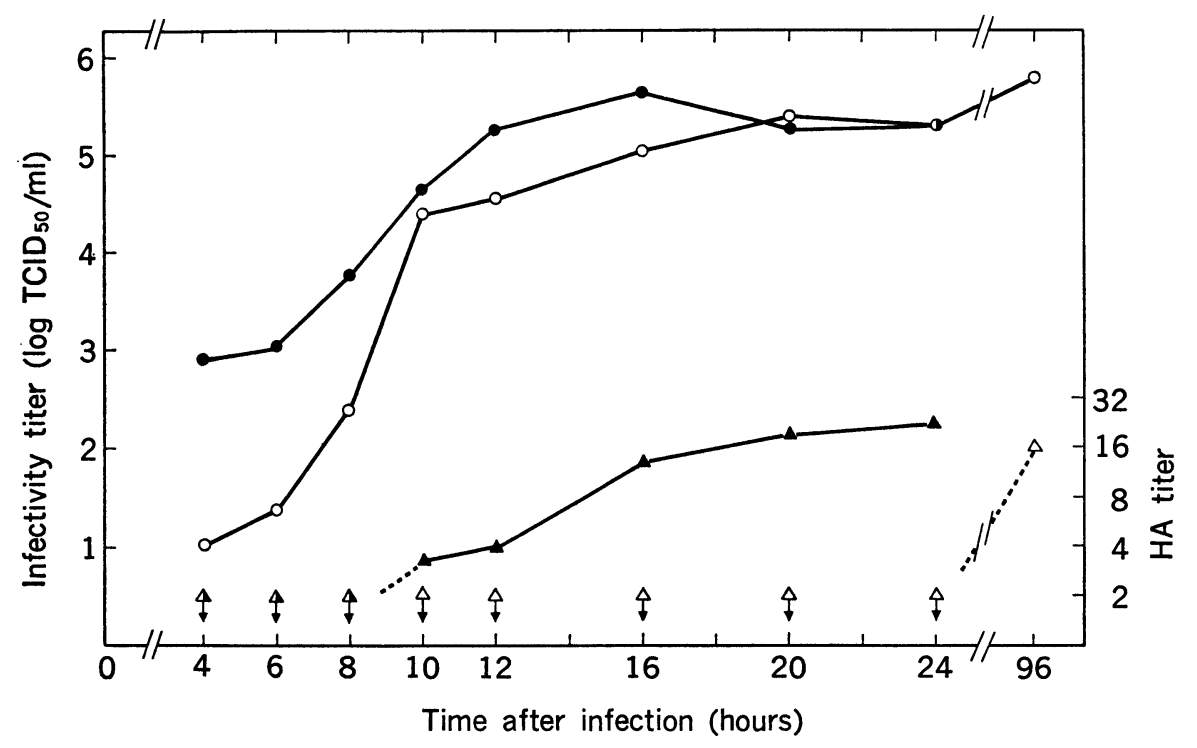

Fig. 1. One-step growth of Murayama virus in MK cells. $\bigcirc-\bigcirc$, virus infectivity titer of culture fluid. $-\square$, infectivity titer of cell-associated virus. $\triangle \longrightarrow \triangle, \mathrm{HA}$ titer of culture fluid. $\Delta-\Delta, \mathbf{H A}$ titer of cells-associated virus.

TABLE I

Growth of Murayama virus in various cell cultures

\begin{tabular}{|c|c|c|c|c|c|c|c|c|}
\hline \multirow{2}{*}{$\begin{array}{l}\text { Cell } \\
\text { culture }\end{array}$} & \multicolumn{4}{|c|}{ The first passage } & \multicolumn{4}{|c|}{ The third passage } \\
\hline & $\begin{array}{c}\text { Virus yield } \\
\left(\mathrm{TCID}_{50} / \mathrm{ml}\right)\end{array}$ & HA titer & CPE & HAD & $\begin{array}{l}\text { Virus yield } \\
\left(\mathrm{TCID}_{50} / \mathrm{ml}\right)\end{array}$ & HA titer & CPE & HAD \\
\hline $\mathbf{M ~ K}$ & $10^{7.8}$ & 128 & Wl & 册 & $10^{7.6}$ & 64 & WI & 曲 \\
\hline C E & $10^{4.0}$ & 16 & + & 世 & $10^{4.2}$ & $<4$ & - & $H$ \\
\hline B H K-21 & $10^{4.5}$ & $<4$ & Wl & 冊 & $10^{4.0}$ & $<4$ & 册 & 冊 \\
\hline Vero & $10^{3.5}$ & $<4$ & - & $H$ & $10^{2.5}$ & $<4$ & - & - \\
\hline LLC-MK2 & $10^{2.8}$ & $<4$ & - & + & $<10^{1.0}$ & $<4$ & - & - \\
\hline MDCK & $10^{3.3}$ & $<4$ & - & + & $<10^{1.0}$ & $<4$ & - & - \\
\hline
\end{tabular}




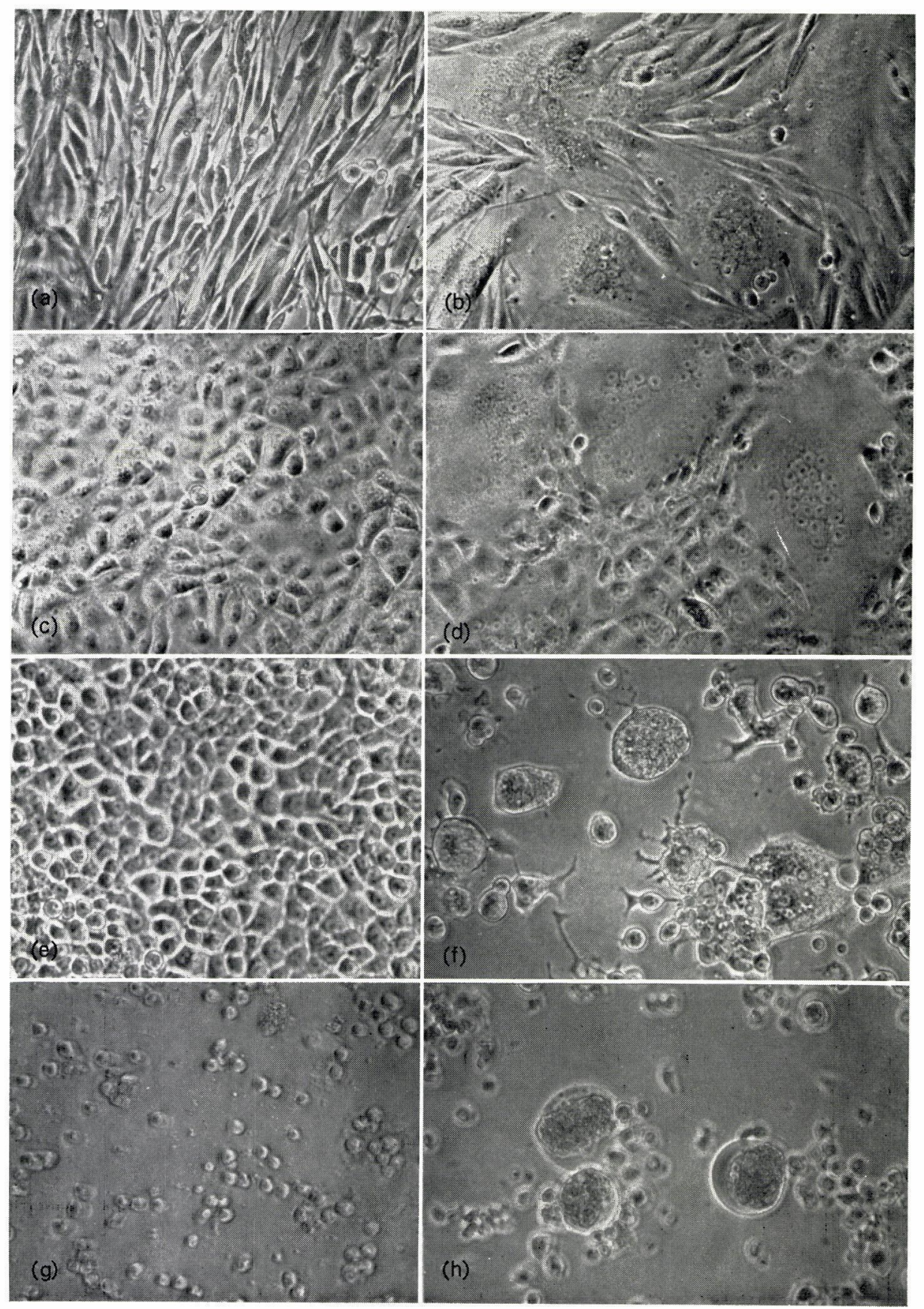

Fig. 2. 
fluids increased exponentially from $6 \mathrm{hr}$ after infection and reached a plateau in $10 \mathrm{hr}$, while the cell-associated virus was detected $4 \mathrm{hr}$ after infection and gradually increased. After 20 to $24 \mathrm{hr}$, the virus titers in the fluids and cells became almost the same. Cytopathic effect (CPE) became detectable $48 \mathrm{hr}$ after infection. In CE and BHK-21 cells, as shown in Table I, the virus yields 5 or 6 days after inoculation were considerably lower than those in MK cells, though those levels of virus yields were maintained for three passages. In $\mathrm{CE}$ cells, weak CPE and moderate HAD were observed. On the other hand, in BHK-21 cells, many large syncytia were formed (Fig. $2 a$ and b) and remarkable HAD was observed, but there was no detectable HA in the culture fluid. In Vero, LLC-MK2 and MDCK cells at the first passage, the virus yields were further lower than those in MK cells 5 or 6 days after inoculation (Table I). At the third passage, only a small virus yield was detected in Vero cells, but no virus yield in LLCMK2 or MDCK cells.

\section{Effect of Trypsin on Virus Growth}

Trypsin is known to enhance the growth of some paramyxoviruses (Morimoto, Doi and Ito, 1970; Itoh et al., 1971; Homma, 1971; Nagai, Klenk and Rott, 1976). Therefore, we examined the effect of trypsin on the growth of Murayama virus in Vero, LLC-MK2 and MDCK cells. As shown in Fig. 3, in Vero and LLC-MK2 cells, infectivity titers reached about $10^{6} \mathrm{TCID}_{50}$ per $\mathrm{ml}$ and large syncytia were observed when $10^{2} \mathrm{TCID}_{50}$ per dish of the virus was inoculated and incubated in the medium with 5 to $30 \mu \mathrm{g}$ of trypsin (Fig. 2c, d, e and f). In MDCK cells, however, we could not observe any virus growth when $10^{6}$ TCID $_{50}$ per dish of the virus was inoculated and incubated in the medium with trypsin. In this case, a low titer $\left(10^{3}\right.$ to $10^{4} \mathrm{TCID}_{50}$ per $\left.\mathrm{ml}\right)$ of infectivity and weak HAD were observed in all ranges of trypsin concentration, probably due to the remaining virus on the cell surface. Nonspecific degeneration of the cells and low titers of HA were also observed at higher concentration ranges of trypsin.

\section{Cell Fusion Activity}

Syncytium formation in cell cultures suggested that Murayama virus could exhibit a cell fusion activity in vitro. Contrary to our expectation, no such activity was observed in EAT cells, which are usually used for detection of the activity of HVJ. On the other hand, positive fusion indices were obtained with Molt- 4 cells as shown by marked giant cells (Table II, Fig. $2 \mathrm{~g}$ and $\mathrm{h}$ ).

Fig. 2. Photomicrographs of infected or fused cell cultures. (a) BHK-21 cells, uninfected. (b) BHK-21 cells, Murayama virus-infected. (c) Vero cells incubated in the absence of trypsin, Murayama virus-inoculated. (d) Vero cells incubated in the presence of trypsin $(10 \mu \mathrm{g} / \mathrm{ml})$, Murayama virus-infected. (e) LLC-MK2 cells incubated in the absence of trypsin, Murayama virus-inoculated. (f) LLC-MK2 cells incubated in the presence of trypsin $(10 \mu \mathrm{g} / \mathrm{ml})$. Murayama virus-infected. (g) Molt-4 cells, control. (h) Molt-4 cells, fused with Murayama virus (magnification $\times 200$ ). 


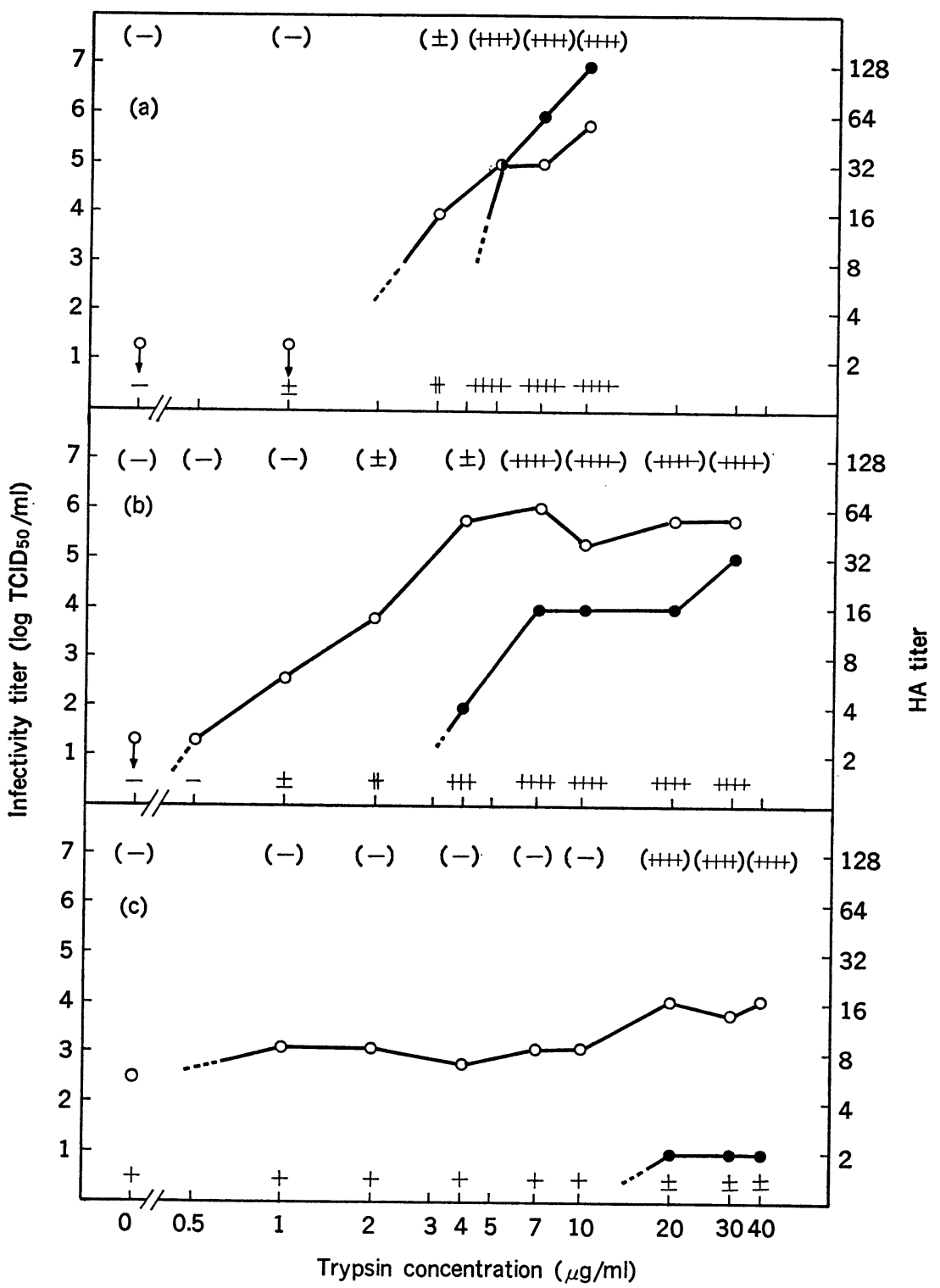

Fig. 3. Effect of trypsin on the growth of Murayama virus in some cell cultures. (a) Vero cells. (b) LLC-MK2 cells. (c) MDCK cells. O-O infectivity titer.

HA titer. + or - in parentheses at the top of each figure indicates the grade of CPE of the cells. + or - at the bottom indicates the grade of HAD. 
TABLE II

Fusion activity of Murayama virus

\begin{tabular}{llrcc}
\hline Cells & Virus & HA titer & $\begin{array}{c}\text { Cell number } \\
\left(\times 10^{4}\right)\end{array}$ & $\begin{array}{c}\text { Fusion } \\
\text { Index }^{* *}\end{array}$ \\
\hline EAT & HVJ & 2,560 & 69 & 5.7 \\
& Murayama & 12,800 & 332 & 0.4 \\
& $-(B S S)^{*}$ & - & 465 & - \\
Molt-4 & Murayama & 6,144 & 233 & 1.1 \\
& $\prime \prime$ & 1,536 & 187 & 1.6 \\
& $\prime \prime$ & 384 & 195 & 1.5 \\
& $\prime \prime$ & 96 & 389 & 0.2 \\
& $-(B S S)$ & - & 484 & - \\
\hline
\end{tabular}

* Balanced salt solution containing $1 \mathrm{mM} \mathrm{CaCl} 2$.

** Fusion Index (FI) was calculated by the following formula as done by Okada and Murayama (1966): $\mathbf{F I}=\frac{\text { Cell number in the control sample without virus }}{\text { Cell number in the test sample }}-1.0$

\section{Influence of Freeze-thawing}

Influence of freeze-thawing on the infectivity and the hemolytic activity of the virus was examined and the results are shown in Fig. 4. Slight decrease in the infectivity was observed after repeated freeze-thawing; after 7 cycle treatments, it was decreased by $10^{0.5}$ and $10^{1.2} \mathrm{TCID}_{50}$ for egg-grown virus and $\mathrm{MK}$ cell-grown virus, respectively. On the other hand, the hemolytic activity was increased after freeze-thawing for both virus materials.

\section{Experimental Infection of Laboratory Animals}

The results are summarized in Table III. Two groups of sero-negative monkeys each consisting of seven animals were tested for susceptibility to the virus either by inhalation or dropping into their nostrils. The virus was isolated from the throat and nasal swabs of all animals everyday for 7 days. The virus was isolated also from one animal each in both inhalation and dropping groups in 10 days, but not at all in 14 days after inoculation. All the animals developed high titers of $\mathrm{HI}$ antibody 2 weeks after inoculation. None of them, however, showed any clinical symptoms nor elevation of body temperature.

Ten mice, four hamsters and three guinea pigs were inoculated with the virus. Half of the mice and hamsters were sacrificed 5 days after inoculation. Localized consolidations were observed in the lungs of two mice and one hamster. The virus was isolated from the mixtures of the lungs of such mice and hamster. Guinea pigs were not sacrificed for virus isolation. Antibody development was demonstrated in all the sera of the hamsters and the guinea pigs in 2 weeks and of the mice in 3 weeks after inoculation. None of the animals showed any symptoms during the observation period. 


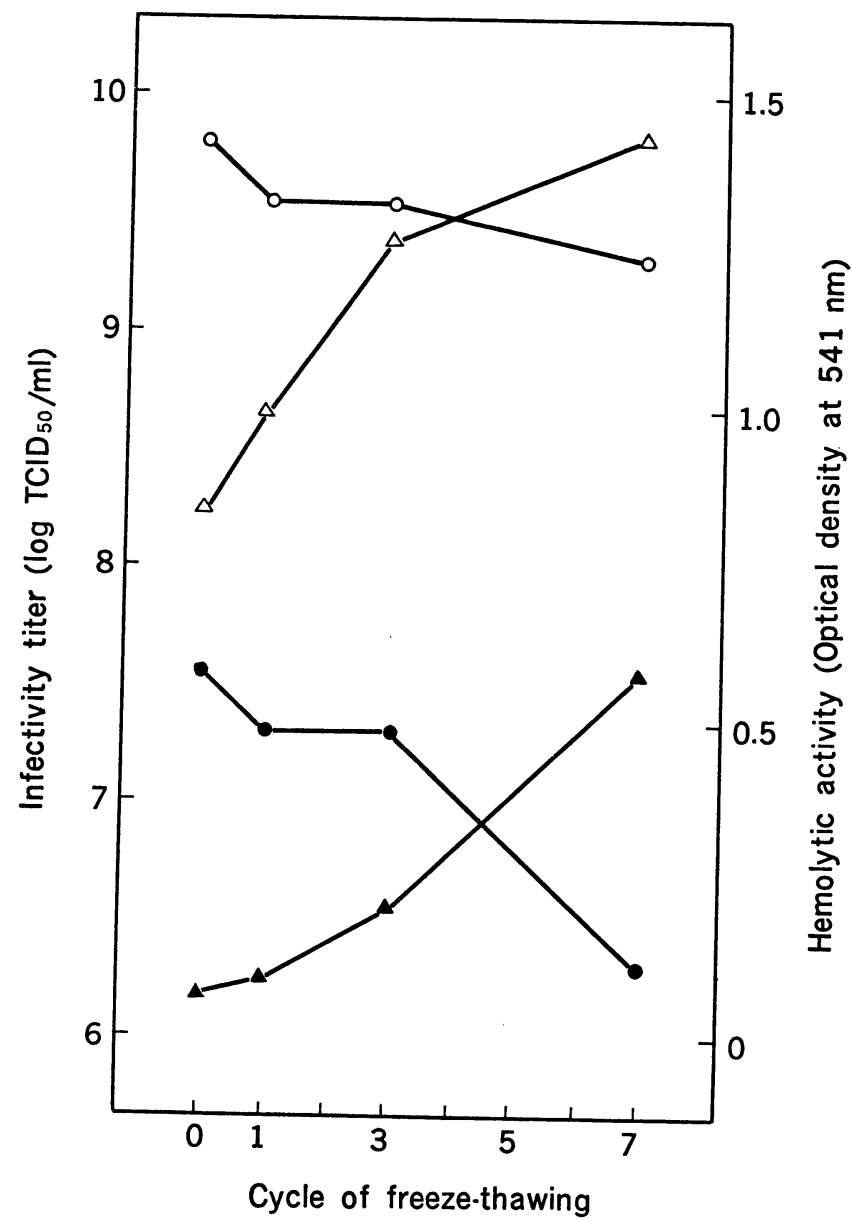

Fig. 4. Effect of freeze-thawing on the infectivity and hemolytic activity of Murayama virus. $O-O$ infectivity titer of egg-grown virus. $\triangle \longrightarrow \triangle$ hemolytic activity of egggrown virus. activity of MK-grown virus.

For bengaleses, four strawberry finches, eight chicks and two quails were inoculated with the virus. In bengaleses, virus was isolated from both the lungtrachea and cloaca 3, 7 and 14 days after inoculation. In strawberry finches, virus isolations were positive in 3 and 7 days after inoculation from both the lungtrachea and cloaca and in 10 days from the cloaca. In chicks, virus was isolated from the lung-trachea and/or cloaca in 3, 7 and 10 days. In a quail, virus was isolated only from the lung-trachea material 5 days after inoculation. None of the birds had antibody to Murayama virus before inoculation. High titers of the antibody were detected in bengaleses and strawberry finches 14 days after inoculation, whereas only low titers in chicks and a quail in 14 days after inocula- 
TABLE III

Experimental infection of laboratory animals and birds with Murayama virus

\begin{tabular}{|c|c|c|c|c|c|c|}
\hline \multirow{2}{*}{$\begin{array}{l}\text { Animals } \\
\text { sand birds }\end{array}$} & \multicolumn{2}{|c|}{ Inoculation } & \multirow{2}{*}{\multicolumn{2}{|c|}{ Virus isolation }} & \multicolumn{2}{|c|}{$\begin{array}{l}\text { Sero-conversion } \\
\text { (HI titer) }\end{array}$} \\
\hline & Route & Volume & & & Pre & Post \\
\hline Monkey & $\begin{array}{l}\text { Inhalation } \\
\text { or i.n. }\end{array}$ & $0.5-1.0 \mathrm{ml}$ & $\begin{array}{l}\text { Nostril and } \\
\text { throat swabs }\end{array}$ & $14 / 14^{3)}$ & $<16$ & $64-512$ \\
\hline Mouse & i.n. & $0.05 \mathrm{ml}$ & Lung & $1 / 1^{4)}$ & $<16$ & $128-512$ \\
\hline Hamster & i.n. & $0.1-0.3 \mathrm{ml}$ & Lung & $1 / 1^{5)}$ & $<16$ & $512-1,024$ \\
\hline Guinea pig & i.n. & $0.1 \mathrm{ml}$ & $\left.\mathrm{NT}^{2}\right)$ & & $<16$ & 128 \\
\hline Bengalese & i.n. & $0.01-0.05 \mathrm{ml}$ & $\begin{array}{l}\text { Lung-trachea } \\
\text { Closaca }\end{array}$ & $\begin{array}{l}3 / 4 \\
3 / 4\end{array}$ & $<32$ & 256 \\
\hline Strawberry finch & i.n. & $0.01-0.05 \mathrm{ml}$ & $\begin{array}{l}\text { Lung-trachea } \\
\text { Cloaca }\end{array}$ & $\begin{array}{l}2 / 4 \\
3 / 4\end{array}$ & $<32$ & 256 \\
\hline Quail & i.n. & $0.05-0.1 \mathrm{ml}$ & $\begin{array}{l}\text { Lung-trachea } \\
\text { Cloaca }\end{array}$ & $\begin{array}{l}1 / 2 \\
0 / 2\end{array}$ & $<16$ & $16-32$ \\
\hline Chicken & i.n. & $0.05-0.1 \mathrm{ml}$ & $\begin{array}{l}\text { Lung-trachea } \\
\text { Cloaca }\end{array}$ & $\begin{array}{l}3 / 8 \\
5 / 8\end{array}$ & $<16$ & 32 \\
\hline
\end{tabular}

1) Intranasally. 2) Not tested. 3) Number positive/Number tested. 4) \& 5) Virus was isolated from a mixture of the lungs of five mice and that of two hamsters.

tion. None of the inoculated birds died nor showed any abnormality during the observation periods.

\section{Discussion}

Among several cell culture systems tested, primary MK cells were most susceptible to Murayama virus producing a high titer of $\mathrm{HA}$ in the fluid and marked HAD and syncytium formation. In contrast to the efficient virus growth in chick embryos, primary CE cells were less susceptible to the virus; the virus yield was much less than that in MK cells and only low titer of HA and weak CPE were detectable. In BHK-21 cells, the virus grew for three passages producing marked HAD and large syncytia, whereas HA was not detected in the culture fluid (Table I, Fig. 2a and b). Such interaction between BHK-21 cells and the virus seems to resemble to that between BHK21-F cells and SV5 (Holmes and Choppin, 1966). Serial passage of the virus was failed in Vero, LLC-MK2 and MDCK cells, but upon addition of trypsin to the medium of Vero and LLC-MK2 cultures, high titers of the virus yield were obtained (Table I, Fig. 3). Similar effects were reported for the growth of HVJ in L cells (Homma, 1971), parainfluenza types 1 and 4 in Vero cells (Morimoto et al., 1970; Itoh et al. 1971) and NDV in MDBK cells (Nagai et al., 1976). It seems probable that Murayama virus grown in Vero or LLC-MK2 cells is not infectious in the respective cells and becomes infectious upon addition of trypsin by the same mechanism as that explained by Homma (1971). In MDCK cells, however, we failed to find any effect of trypsin on growth of Murayama virus although a high moi of the virus was inoculated. 
Cell fusion activity of the virus was demonstrated in Molt-4 cells but not in EAT cells (Table II, Fig. $2 \mathrm{~g}$ and $\mathrm{h}$ ). Since neither cell agglutination nor cell fusion was observed in the mixture of the virus and EAT cells, the receptor for HVJ involving a sialo-compound located on the surface of EAT cells seemed unlikely to be functional as the receptor for Murayama virus.

Hemolytic activity is observed in many paramyxovirus (Morgan, Enders and Wagley, 1948; Kilham, 1949), and this activity of HVJ is enhanced by freezethawing (Hosaka, 1958). Hemolytic activity of Murayama virus also appeared to be enhanced by freeze-thawing (Fig. 4). The present results indicated that the mechanism of the activity of Murayama virus might be the same as that of $\mathrm{HVJ}$ (Homma et al., 1976; Shimizu et al., 1976).

The previous serological survey of monkeys for Murayama virus performed in this laboratory disclosed that the Murayama virus-infected monkeys belonged to the group of the same shipment and were imported together with exotic pet birds by the same airplane (Nishikawa et al., 1977a). Therefore, a question arose whether this virus came from the bird. One virus among several paramyxoviruses isolated from the exotic pet birds arriving at Haneda Airport, Tokyo (Nishikawa et al., 1977b) was found to be closely related to Murayama virus in the antigenicity (unpublished data).

In the present investigation, experimental infections of some mammalians and birds with Murayama virus were attempted, and all these animals were found to be susceptible to the virus by isolating the virus and demonstrating seroconversions (Table III). However, none of these animals showed any clinical signs. From these results, it is difficult to speculate upon the origin of Murayama virus.

\section{Acknowledgement}

We would like to thank Dr. T. Fujiwara and Dr. M. Takasaka, Department of Veterinary Science, N.I.H., for their co-operation in the experimental infection to monkeys.

\section{REFERENCES}

Alexander, D. J., Aymard, M., Kessler, N. And Collins, M. S. (1979): Antigenic and structuarl relationships between avian paramyxoviruses isolated from ducks in Hong Kong and Mississippi, U.S.A. J. Gen. Virol., 44, 839-842.

Collings, D. F., Fitton, J., Alexander, D. J., Harkness, J. W. and Pattison, M. (1975): Freliminary characterization of a paramyxovirus isolated from a parrot. Res. Vet. Sci., 19, 219-221.

Holmes, K. V. And Choppin, P. W. (1966): On the role of the response of the cell membrane in determining virus virulence. Contrasting effects of the parainfluenza virus SV5 in two cell types. J. Exptl. Med., 124, 501-519.

Номма, M. (1971): Trypsin action on the growth of Sendai virus in tissue culture cells. J. Virol., 8, 619-629.

Homma, M., Shimizu, K., Shimizu, Y. K. And Ishida, N. (1976): On the study of Sendai virus hemolysis. I. Complete Sendai virus lacking in hemolytic activity. Virology, 71, 41-47.

Hosaka, Y. (1958): On the hemolytic activity of HVJ. I. An analysis of the hemolytic reaction. Biken's J., 1, 70-89 .

Itoh, H., Morimoto, Y., Okawa, S., Doi, Y., Sanpe, T., Nakajima, M., Katoh, T. and Sogawa, Y. 
(1971): Serial passage of parainfluenza type 1 (HA-2) virus in the continuous cell lines from porcine, rabbit and green monkey kidneys using the trypsin-added systems. Japan. J. Med. Sci. Biol., 24, 387-391.

Kilmam, L. (1949): A newcastle disease virus (NDV) hemolysin. Proc. Soc. Exp. Biol. Med., 71, 63-66.

McFerran, J. B., Connor, T. J., Allan, G. M. And Adair, B. (1974): Studies on a paramyxovirus isolated from a finch. Arch. ges. Virusforsch., 46, 281-290.

Minowada, J., OHnuma, T. AND Moore, G. E. (1972): Rosette-forming human lymphoid cell lines. I. Establishment and evidence for origin of thymus-derived lymphocytes. J. Natl. Cancer Inst., 49, 891-895.

Morgan, H. R., Enders, J. F. And Wagley, P. F. (1948): A hemolysin associated with the mumps virus. J. Exptl. Med., 88, 503-514.

Morimoto, Y., Dor, Y. AND ITOH, H. (1970): Effect of trypsin on reproduction of type 4 parainfluenza virus in Vero cell cultures under fluid overlay. Japan. J. Med. Sci. Biol., 23, 1-11.

NAGAI, Y., KLENK, H.-D. AND RoTr, R. (1976): Proteolytic cleavage of the viral glycoproteins and its significance for the virulence of newcastle disease virus. Virology, 72, 494-508.

Nishikawa, F., Sugiyama, T. ANd Suzuki, K. (1977a): A new paramyxovirus isolated from cynomolgus monkeys. Japan. J. Med. Sci. Biol., 30, 191-204.

Nishikawa, F., SugiYama, T., Yamamoto, K. ANd Yonemura, H. (1977b): Isolation of influenza type A viruses from imported pet birds. Japan. J. Med. Sci. Biol., 30, 31-36.

OKadA, Y. AND Murayama, F. (1966): Requirement of calcium ions for the cell fusion reaction of animal cells by HVJ. Exptl. Cell Res., 44, 527-551.

Shimizu, Y. K., Shimizu, K., Ishida, N. And Homma, M. (1976): On the study of Sendai virus hemolysis. II. Morphological study of envelope fusion and hemolysis. Virology, 71, 48-60.

Shortridge, K. F. AND AleXANDER, D. J. (1978): Incidence and preliminary characterization of a hitherto unreported, serologically distinct, avian paramyxovirus isolated in Hong Kong. Res. Vet. Sci., 25, 128-130.

Smit, Th. And Rondhuis, P. R. (1976): Studies on a virus isolated from the brain of a parakeet (Neophema $s p$ ). Avian Pathol., 5, 21-30.

Toвita, K. (1975): Permanent canine kidney (MDCK) cells for isolation and plaque assay of influenza B viruses. Med. Microbiol. Immunol., 162, 23-27.

Webster, R. G., Morita, M., Pridgen, C. ANd Tumova, B. (1976): Orth- and paramyxoviruses from migrating feral duck: Characterization of a new group of influenza A viruses. J. Gen. Virol., 32, 217-225.

Yamane, N., Odagiri, T., Arikawa, J., Morita, M., Sukeno, N. And Ishida, N. (1978): Isolation of orthomyxoviruses from migrating and domestic ducks in northern Japan in 1976-1977. Japan. J. Med. Sci. Biol., 31, 407-415. 